\title{
Isolation of Aspergillus parasiticus and Detection of Aflatoxin B1 on Local Peanut (Arachis hypogaea L.) Varieties in Bali
}

\author{
A.S. Duniaji*, W. Putu Arisandhi, N.N. Puspawati and C.D. Ni Putu Novilia \\ Department of Food Science and Technology University of Udayana Bali, Indonesia \\ *Corresponding author
}

\section{A B S T R A C T}

This study was aimed to determine the contamination of Aspergillus parasiticus and

Keywords

Local peanuts, $A$. parasiticus, Aflatoxin B1

Article Info

Accepted:

26 July 2018

Available Online:

10 August 2018 aflatoxin B1 on Local varieties of peanuts in Bali. A total of 18 Local varieties of peanut were taken at several farmers in the field on each district in Bali. This study used descriptive analysis that showed in the form of figure and table. Samples were isolated using PDA (Potato Dextro Agar) during the incubation period 5 days (120 hours) at room temperature $\left(29^{\circ} \mathrm{C}\right)$ and further purified by the media DRBC (Dichloran Rose Bengal Chlorampenicol) and Aflatoxin B1 was analyzed using the Enzyme Linked Immunosorbent Assay (ELISA) [Chinaphuti, 2003]. The results showed A. parasiticus contaminated Local varieties of peanuts are the lowest in Bali on the sample Amlapura Local 1, Gianyar Local 1, Mangupura Local 1 and Tabanan Local 1 were $1.0 \times 10^{4} \mathrm{cfu}$ $\mathrm{ml}^{-1}$, and the highest population present in the sample Singaraja Local 1 was $1.0 \times 10^{5} \mathrm{cfu}$ $\mathrm{ml}^{-1}$. Aflatoksin B1 content of the peanut contaminating Local varieties ranged from $2.4 \pm$ $0.57 \mathrm{ppb}-100 \mathrm{ppb}$. Local varieties of peanuts for consumption according to Codex standards maximal $15 \mathrm{ppb}$ is $94.4 \%$ (ranged from $0-15 \mathrm{ppb}$ )

\section{Introduction}

In the early 1960s, many laboratories focused their attention on an outbreak of hepatotoxic disease in turkeys and other poultry (turkey $\mathrm{X}$ disease), a problem affecting animals worldwide (Anonymous, 2004).

Turkey $\mathrm{X}$ disease was attributed to contamination of peanut meal with aflatoxins, toxic metabolites produced by some strains of Aspergillus flavus, A. parasiticus, and A. nomius (Boutrip, 1977; Chinaphuti, 2003). Strains of $A$. flavus and A. parasiticus can produce aflatoxins $\mathrm{B} 1, \mathrm{~B} 2, \mathrm{G} 1, \mathrm{G} 2$ and $\mathrm{M}$
(Cullen and Newberne, 1994), contaminating a number of agricultural products such as peanuts, corn, and cereal grains (Dharmaputra, 1999). Aflatoxin contamination occurs by colonization of the fungus on susceptible crops, or may arise during harvesting, drying, storage, or processing.

Peanut is a legume commodity product in Indonesia, which are mostly used for the purpose of consumption. The production of peanuts in Bali reached 11.582 tons (1). The figure shows the highest production compared to soy production reached 5.555 tons and a total of 753 tons of green beans. 
The top position peanuts as a source of cash income for farmers in Indonesia (Kasno, 2005). However, the presence of impurities of boletus in peanuts cause losses not least, because the percentage of boletus are infecting peanut in Indonesia is quite high. The main species that contaminate peanut A. flavus and A. parasiticus (Pitt et al., 1998), with the resulting toxin called aflatoxin.

Crops contaminate most nuts and is a major problem in the world. In Australia the major crops has been a problem in the peanut industry since 20 years ago, but has now become a major issue for the industry food safety (Johnson, 1997). Aflatoxin poisoning does not lead to acute, but in chronic liver organ disorders cause. However until now in Indonesia such issues have not been a serious attention from various parties, to control aflatoxin contamination problems and resolve them.

The presence of contamination of boletus in peanuts cause high economic losses among other occur automatic detention (imprisonment) against Indonesia in agricultural commodities in the world market, the loss of agricultural products that are quite high (cannot be consumed/sold) (Kozakiewics, 1995).

Aflatoxin contamination in peanut seed is an important issue to the quality of food around the world. The percentage of samples contaminated peanut aflatoxin and aflatoxin total deposits increased from $35 \%$ to $55 \%$, from range 19.4-39.8 ppb become 10.1-88.5 ppb. Two types of aflatoxin are found which are B1 and B2, which types of crops which are most frequently found is $\mathrm{B} 1$.

Based on the research done the isolation of $A$. parasiticus and the detection of aflatoxin B1 of local peanuts (Arachis hypogeae L.) varieties in Bali.

\section{Materials and Methods}

\section{Sample preparation}

The materials used in the study include peanut varieties obtained from local farmers in Bali, media Potato dextrose agar (PDA), media DRBC (Dichloran Rose Bengal Chlorampenicol) consisting of $10 \mathrm{~g}$ of glucose, $5 \mathrm{~g}$ of peptone, $1 \mathrm{~g}$ of $\mathrm{KH} 2 \mathrm{PO} 4$, 0.05 gram $\mathrm{MgSO}_{4} 7 \mathrm{H}_{2} \mathrm{O}, 0.05 \mathrm{~g}$ rose Bengal, $0.01 \mathrm{~g}$ of chloramphenicol, 0.2 dichloran in ethanol $1 \mathrm{ml}$ of sterile water, pH 5.6 (King et al., 1979), Whattman No 2, methanol, alcohol $96 \%$, Test Kit of aflatoxin B1 (Chinaphuti, 2003).

This research carried out in the laboratory of Microbiology Laboratory, Faculty of agricultural technology, Laboratory of Veterinary of Province of Bali. Sampling was done randomly at centre of peanut production, where each sample specified taken to more farmers. A total of 18 Local varieties of peanut were taken at several farmers in the field on each district in Bali. 500-1000 $\mathrm{g}$ of sample of peanut was taken ranges between of material chosen at random. This research used descriptive analysis that showed in the form of figure and table. The description of the 18 samples were obtained from each Center for agriculture in the 9 districts in Bali can be seen in table 1.

\section{Isolation and identification}

A. parasiticus was isolated from 18 samples of peanut Varieties in 9 Local district in Bali. Peanuts are cleaned first with water, then crushed with a sterile blender. $10 \mathrm{~g}$ of the sample taken and entered into $90 \mathrm{ml}$ of sterile water in an Erlenmeyer flask. Then as much as $1 \mathrm{ml}$ inoculated in the Petri dish was filled with media PDA. Cultures incubated in room temperature for 5 days (120 hours), therefore was done identification. 
The isolates $A$. parasiticus was isolated using cork borer to be inoculated in DRBC medium and then stored for 5 days (120 hours) in room temperature. Identification is done by observing isolates A. parasiticus in microscope

\section{Detection of Aflatoxin B1}

$20 \mathrm{~g}$ of samples weighed and put into blender add $100 \mathrm{ml}$ of methanol 70 on a sample, then the most high speed blender for 2-3 minutes. After samples destroyed filtered using filter paper Whatman No. 4 and strain samples to extract a clear look. The filtrate is accommodated as many as $1.0 \mathrm{ml}$ with microtubule and and added $1 \mathrm{ml}$ of sterile water.

A standard solution of aflatoxin $(0 ; 0.2 ; 0.5 ; 1$, 2 and $5(\mathrm{ng} / \mathrm{ml}))$ and a sample of $50 \mu \mathrm{l}$ put into the micro wells, incorporated into the respective wells. Wells that already contain standard and sample each added enzyme conjugate to each well $50 \mu \mathrm{l}$ and wells incubated for $30 \mathrm{~min}$ at room temperature and dark spaces. The liquid in the micro wells subsequently disposed outside on tissue paper clean and washed with sterile water. The work was repeated four times.

A substrate contains 3.3 ' 5,5 'Tetramethylbenzidine $0.4 \mathrm{~g} / \mathrm{l}$ in alkaline organic and substrate B contains $0.02 \mathrm{H} 2 \mathrm{O} 2$ in citric acid buffer. Substrates A and B mixed 30 minutes earlier. Later added as much as $100 \mu \mathrm{l}$ into wells is blended well and incubated for 5 minutes at room temperature and dark spaces.

The solution contains $0.01 \mathrm{M}$ stop reaction of phosphate acid as much as $100 \mu$ l added into respective wells. Further reading absorbance on the activities of the micro wells by ELISA Reader at a wavelength of $450 \mathrm{~nm}$. OW to calculate number of aflatoxin in peanuts is
$\%$ absorbnsi $=\frac{\mathrm{B}}{\mathrm{B} 0}$

\section{Description}

$\mathrm{B}$ : the value of absorbance of each sample B0 standard: the value of absorbance in 0

A Total of aflatoxin contained in each sample can be calculated using paper millimeters. Where $\mathrm{X}$ is a line of standard aflatoxin B1 concentration while the maximum absorbance indicates each Y sample (Chinaphuti, 2003).

\section{Results and Discussion}

\section{Characteristic of $A$. parasiticus}

The research was conducted on 18 samples of local peanut varieties obtained from each distric in Bali. Isolation of $A$. parasiticus using media DRBC (Dichloran Rose Bengal Chlorampenicol) and medium PDA (potato dextro to) local varieties of peanuts during the incubation period of 5 days can be seen in Figure 1.

Figure 1 can be seen $A$. parasiticus color green darkness colonies commonly called ivy green in colour (King et al., 1979). A. parasiticus can germinate on surface wounds from crops (corn and beans). Then penetrate against the growth of the embryo. Observations with the microscope showed morphological forms of $A$. parasiticus as in Figure 2.

\section{Description:}

$\mathrm{A}=$ mold Aspergillus parasiticus: stigmata

$\mathrm{B}=$ vesicles of the mold Aspergillus parasiticus

$\mathrm{C}=$ mold Aspergillus parasiticus konidia 
$\mathrm{D}=$ konidiofor mold Aspergillus parasiticus

According to (Pitt and Hocking, 1997), A. parasiticus has conidiophore that emerges from the surface of the Harare International Festival of the -500 length $250 \mu \mathrm{m}$, colorless or light brown and smooth-walled; spherical vesicles with diameter $20 \mu \mathrm{m}$ and -35 only $3 / 4$ of the surface of the vesicles in the fertile (fertile); vesicles form the phialide-11 $\mu \mathrm{m}$ long, 7 conidia producing spherical, usually $4-$ $6 \mu \mathrm{m}$ in diameter, rough-shaped cell walls and usually forms the head of the conidia of the round (King et al., 1979; Pitt and Hocking, 1997). A. parasiticus is growing at between 12-40 $\circ \mathrm{C}$ with an optimum growth temperature of $30^{\circ} \mathrm{C}$; the value of aw minimum for growth was 0.82 at a temperature of $25^{\circ} \mathrm{C}, 0.81$ at a temperature $30^{\circ} \mathrm{C}$ and at a temperature of $37^{\circ} 0.80 \mathrm{C}$ and $\mathrm{pH}$ between 1.5-10.5 on the temperature of the third (Pitt and Hocking, 1997).

\section{Population of A. parasiticus}

Research results of the 18 samples of local peanut varieties obtained from local farmers in each district in Bali, showed a variation of $A$. parasiticus on local varieties of peanuts. In Table 3 can be seen the population of $A$. parasiticus, which contaminate local peanut varieties.

The Table 3 can be seen that the population of A. parasiticus, which contaminate local peanut varieties was vary. The smallest population is $10 \times 103$ cfu.ml $^{-1}-10.2 \times 104$ cfu.ml ${ }^{-1}$. The population of $A$. parasiticus is lowest in samples of AL1, GL1, ML1 and TL1 was $10 \mathrm{x}$ $103 \mathrm{cfu}^{-\mathrm{ml}^{-1}}$. While the highest populations are present in a sample of SL2 are $10.2 \times 104$ cfu.ml ${ }^{-1}$. This is caused by A. parasiticus growth ability on optimum temperature $32{ }^{\circ} \mathrm{C}$ growth; the value of the minimum for the growth is the aw 0.82 at a temperature of $25^{\circ}$ $\mathrm{C}$; 0.81 at a temperature of $30^{\circ} \mathrm{C}$ and at a temperature of $37^{\circ} 0.80 \mathrm{C}$ and $\mathrm{pH}$ between 1.5-10.5 on the temperature of the third (King et al., 1979; Pitt and Hocking, 1997). According to (King et al., 1979; Kuswantoro and Sudarmadji, 1988). Since in the soil, during drying and storage can be covered by the mold A. parasiticus and A. flavus. Suitable Habitat for the growth of the mold is the moisture content of 14-30 and a temperature between $21-37^{\circ} \mathrm{C}$. In the closed storage and aeration conditions less encourage mold growth.

\section{Aflatoksin B1 content of peanut}

Results of the analysis of the content of aflatoxin $\mathrm{B} 1$ on the 18 samples of local peanut varieties taken of farmers in each district in Bali can be seen in Table 4.

In the Table 4 can be seen that there are variations in contamination AFB1 of local peanut varieties. Contamination AFB1 in local peanut varieties ranges from $1.5-14 \mathrm{ppb} \mathrm{ppb}$, while samples of the DL2 in excess of 100 $\mathrm{ppb}$

Variation of aflatoxin content in peanuts can be caused by several factors, namely crops can be produced by $A$. parasiticus at between $12-$ $40^{\circ} \mathrm{C}$, the water activity (Aw) 0.86 and $\mathrm{pH} 3$ 8 (13). According to (Jay, 2000), formation of aflatoxin pad peanuts occurred at optimum $0.93-0.98$ aw and RH $83 \%$ or higher at a temperature of $30^{\circ} \mathrm{c}$. the ability of mold to form and store crops depends on several factors including genetic potential mold requirements-environmental requirements (substrate, temperature, humidity, and $\mathrm{pH}$ ) and duration of contact between the mould and the substrate.

Aflatoxin production is strongly influenced by the presence of mold, interaction between the substrate and the environmental conditions (Saad, 2001; Duniaji, 2009). 
Table.1 Providing the code in samples obtained from each district in Bali

\begin{tabular}{|l|l|}
\hline Sample & Sample at Distric of Bali \\
\hline SL1 & Farmer at Singaraja 1 \\
\hline KL1 & Farmer at Amlapura 1 \\
\hline GL1 & Farmer at Klungkung 1 \\
\hline BL1 & Farmer at Gianyar 1 \\
\hline DL1 & Farmer at Bangli 1 \\
\hline ML1 & Farmersat Denpasar 1 \\
\hline TL1 & Farmersat Mangunpura 1 \\
\hline NL1 & Farmer at Tabanan 1 \\
\hline Sample & Farmer at Negara 1 \\
\hline SL2 & Fample at Distric of Bali \\
\hline AL2 & Farmer at Amgaraja 2 \\
\hline KL2 & Farmer at Klungkung 2 \\
\hline GL2 & Farmer at Gianyar 2 \\
\hline BL2 & Farmer at Bangli 2 \\
\hline DL2 & Farmer at Denpasar 2 \\
\hline ML2 & Farmer at Mangunpura 2 \\
\hline TL2 & Farmer at Tabanan 2 \\
\hline NL2 & Farmer at Negara 2 \\
\hline
\end{tabular}

Table.2 Population of A. parasiticus that contaminated local peanuts varieties in Bali (cfu.mll ${ }^{-1}$ )

\begin{tabular}{|l|l|l|l|l|l|}
\hline Sample & $\begin{array}{l}\text { A. parasiticus } \\
\left(\text { cfu.ml }^{-1}\right)\end{array}$ & Other fungi & Sampel & $\begin{array}{l}\text { A. parasiticus } \\
\left(\text { cfu.ml }^{\mathbf{1}}\right)\end{array}$ & Other fungi \\
\hline SL1 & $50 \times 10^{3}$ & $84 \times 10^{2}$ & SL2 & $10,2 \times 10^{4}$ & $58 \times 10^{2}$ \\
\hline AL1 & $10 \times 10^{3}$ & $20 \times 10^{3}$ & AL2 & - & $40 \times 10^{3}$ \\
\hline KL1 & $25 \times 10^{2}$ & $95 \times 10^{2}$ & KL2 & $20 \times 10^{3}$ & $20 \times 10^{2}$ \\
\hline GL1 & $10 \times 10^{3}$ & $90 \times 10^{3}$ & GL2 & $20 \times 10^{3}$ & $90 \times 10^{3}$ \\
\hline BL1 & $50 \times 10^{3}$ & $28 \times 10^{2}$ & BL2 & $10 \times 10^{2}$ & $37 \times 10^{2}$ \\
\hline DL1 & - & $30 \times 10^{3}$ & DL2 & $20 \times 10^{3}$ & $90 \times 10^{3}$ \\
\hline ML1 & $10 \times 10^{3}$ & $10 \times 10^{3}$ & ML2 & $40 \times 10^{3}$ & $17 \times 10^{2}$ \\
\hline TL1 & $10 \times 10^{3}$ & $40 \times 10^{3}$ & TL2 & $40 \times 10^{3}$ & $90 \times 10^{3}$ \\
\hline NL1 & $90 \times 10^{3}$ & $30 \times 10^{3}$ & NL2 & $12 \times 10^{2}$ & $40 \times 10^{3}$ \\
\hline
\end{tabular}

Table.3 Aflatoxin B1 content in peanut of local varieties in Bali

\begin{tabular}{|c|c|c|c|}
\hline Sample & Aflatoxin B1 (ppb) & Sample & Aflatoxin B1 (ppb) \\
\hline SL1 & $10.4 \pm 0.14$ & SL2 & $4.8 \pm 0.57$ \\
\hline AL1 & $10.8 \pm 0.28$ & AL2 & $8.4 \pm 0.28$ \\
\hline KL1 & $8.2 \pm 0.28$ & KL2 & $4.8 \pm 0.28$ \\
\hline GL1 & $8.0 \pm 0.28$ & GL2 & $7.4 \pm 0.57$ \\
\hline BL1 & $9.2 \pm 0.57$ & BL2 & $6.6 \pm 0.28$ \\
\hline DL1 & $4.0 \pm 0.28$ & DL2 & 100 \\
\hline ML1 & $8.4 \pm 0.28$ & ML2 & $14.0 \pm 0.28$ \\
\hline TL1 & $3.6 \pm 0.28$ & TL2 & $5.6 \pm 0.28$ \\
\hline NL1 & $8.0 \pm 0.57$ & NL2 & $2.4 \pm 0.57$ \\
\hline
\end{tabular}


Table.4 The proportion of AFB1 on local varieties of peanut

\begin{tabular}{|c|c|}
\hline Content of AFB1(ppb) & Proportion (\%) \\
\hline $\mathbf{0 - 5}$ & 27,78 \\
\hline $\mathbf{5 - 1 0}$ & 44,44 \\
\hline $\mathbf{1 0 - 1 5}$ & 22,22 \\
\hline $\mathbf{1 0 0}$ & 5,56 \\
\hline
\end{tabular}

Fig.1 A. parasiticus in media the DRBC incubated for 5 days (120 hours) at room temperature
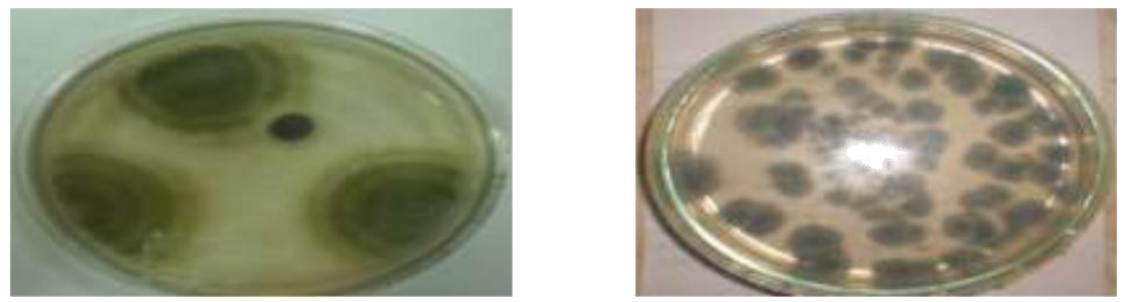

Fig.2 A. parasiticus is observed with a microscope with a magnification of 400x
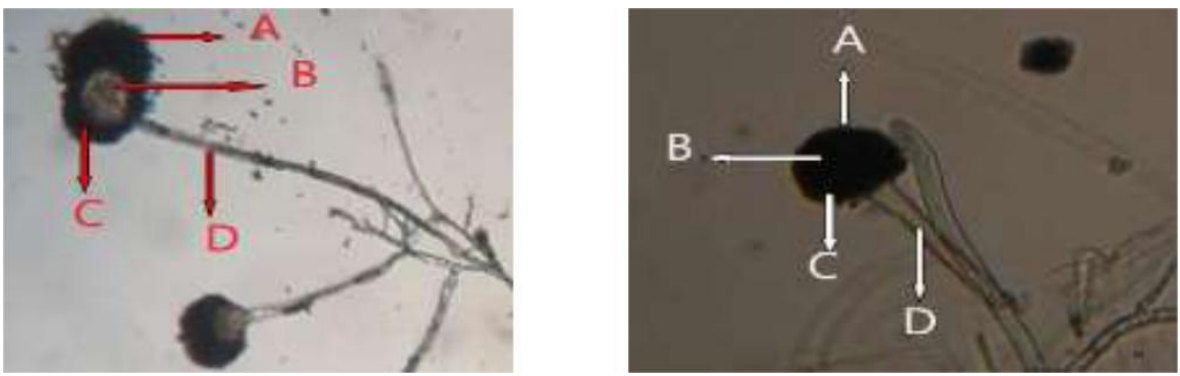

Fig.3 Test results ELISA AFB1 in ground nuts local varieties

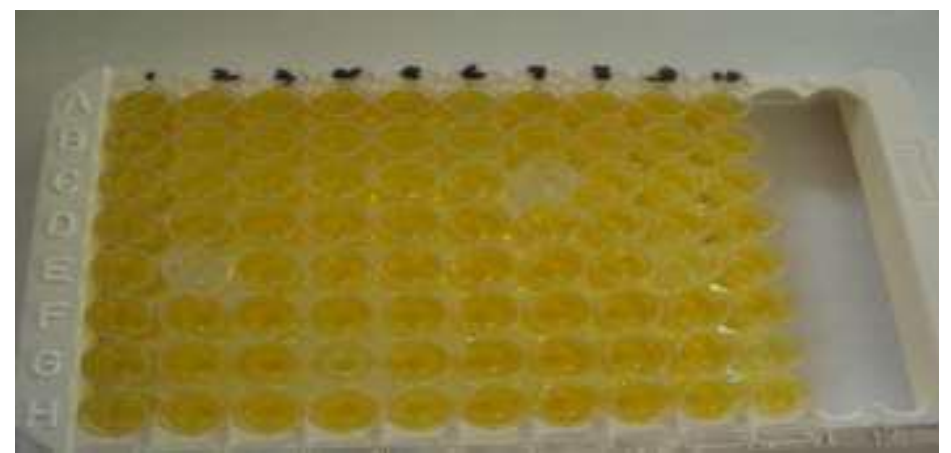

Aflatoxin is produced by $A$. flavus and $A$. parasiticus on groceries will be spurred its creation in the depressed mold condition (stress), due to the limited nutrition and environmental temperature is high (Boutrip, 1977; Dharmaputra et al., 2005). A high concentration of aflatoxin can also occur as a result of poor post-harvest handling especially during storage under conditions of high humidity, which also occurred in field before harvest (Bankole and Mabekoje, 2004). According to Kozakiewics (1995), Duniaji 
(2009). States the drought (water stress), high temperature and insect destroyer host plants is a major factor and the production of aflatoxin mould infestations.

ELISA test results showed a discoloration of the substrate on the samples examined. Yellow color on the test substrate ELISA shows a lower content of AFB1 compared to the clear color on the ELISA test. In Figure 3 the ELISA test results can be seen in the sample the local varieties of peanuts.

Figure 3 indicates that the yellow color is obtained after using stopping reactions on substrates before reading absorbance at micro wells with an ELISA Reader at a wavelength of $450 \mathrm{~nm}$. The comparison of the color yellow shows more the low content of AFB1. Instead the more nodes the higher content of AFB1.

Requirements/standards of the Codex alimentary Commission the maximum content of AFB1 in ground nuts is $15 \mathrm{ppb}$. Based on it can be noted that the proportion of local varieties of peanuts aflatoxin B1 contaminated in Bali. Can be seen in Table 5.

Table 5 can be seen that the proportion of AFB1 was found 27, 78 percent at 5 samples (DL1, TL1, SL2, KL2, NL2) range 0-5 ppb. It was found 44.44 percent of 9 samples (KL1, GL1, BL1, ML1, NL1, AL2, GL2, BL2, TL2) Ranging 5-10 ppb and 22.22 percent was found at 3 sample (SL1, AL1, ML2) range 10-15 ppb., while the range more than 100 ppb sample (DL2) is 5,56 percent and these samples was not recommended for consumable. Aflatoxin was found in the highest sample DL2 which is more than 100 $\mathrm{ppb}$, whereas the lowest aflatoxin content of the sample NL2 is $4 \mathrm{ppb}$. While the standard FDA United States (USFDA) and the Food Drug Administration (FDA) maximum of AFB1 Indonesia on peanuts is $20 \mathrm{ppb}$
Sample (DL2) is unfit for consumption due to the aflatoxins content more than $100 \mathrm{ppb}$ that is in excess of the standards. According to (Chinaphuti, 2003; Loosmore and Marksman, 1961; Wilson and Payne, 1994), the standards of the Codex Alimentary Commission recommends the content of aflatoxin $15 \mathrm{ppb}$ (AFB1, AFB2, AFG1, AFG2) on peanuts and aflatoxin M1 0,05 ppb in the milk. According to FDA standards established Indonesia since 9 September 2004 namely the content of aflatoxin B1 and total aflatoxin in peanuts processed by 20 and $35 \mathrm{ppb}$ (Busby and Wogan, 1984)

A. parasiticus contaminated local varieties of peanuts are the lowest in Bali on the sample Amlapura Local 1, Gianyar Local 1, Mangupura Local 1 and Tabanan Local 1 was $1.0 \times 10^{4} \mathrm{cfu} \mathrm{ml}^{-1}$, and the highest population present in the sample Singaraja Local 1 is 1.0 X $10^{5} \mathrm{cfu} \mathrm{ml}^{-1}$. Aflatoksin B1 content of the peanut contaminating local peanut varieties ranged from $2.4 \mathrm{ppb}-14.0 \mathrm{ppb}$. Local varieties of peanuts for consumption according to Codex standards maximal 15 ppb is $94.4 \%$.

\section{References}

Anonymous. 2004. Agricultural Statistics. The Department Of Agriculture. Jakarta Anonymous. 2010. Bali in figures. The Department Of Agriculture. Bali

Asao, T., G. Buchi, M.M. Abdel-Kader, S.B. Chang, E.L. Wick, G.N. Wogan, Aflatoxins B and G, J. Am. Chem. Soc. 85 (1963) 1706-1707.

Asplin, F.D., R.B.A. Carnaghan, The toxicity of certain groundnut meals for poultry with special reference to their effect on ducklings and chickens, Vet. Rec. 73 (1961) 1215-1219.

Bankole, S.A. and Mabekoje, O.O. 2004. Occurring of aflatoxins and Fumonisins in Preharvest Maize from South-western 
Nigeria. Food additive and Contaminants, 21, 251-255.

Boutrip, E. 1977. Prevention of Mycotoxin in Pitachios. Division Food quality and Standards Service. FAO Food and Nutrition, Pitachios '97 Conference, Rome, Italy. Pp 1-12.

Busby, W.F., and G.N. Wogan, Aflatoxin, in: C.E. Searle (Ed.), Chemical Carcinogens, American Chemical Society, Washington, DC, 1984, pp. 945-1136.

Chinaphuti, A. 2003. Aflatoxins in Peanuts and Peanuts Product. Workshop on Handling and Measurement of the Quality of Peanut and Peanut Products Held by Katsersart University, CRSP and USAID in Bangkok Thailand (2003)

Cullen, J.M., and P.M. Newberne, Acute hepatotoxicity of aflatoxins, in: D.L. Eaton, J.D. Groopman (Eds.), The Toxicology of Aflatoxins; Human Health, Veterinary, and Agricultural Significance, Academic Press, San Diego, CA, 1994, pp. 3-26.

Dharmaputra OS, Putri ASR, Retnowati I, Ambarwati S. 2005. Soil mycobiota of peanut fields in Wonogiri regency, Central Java: Their effect on the growth and aflatoxin production of Aspergillus flavus in vilro. Biolropia 17:30-58.

Dharmaputra OS. 1999. Review on fungi and mycotoxins in Indonesian commodities. Di dalam: Jin ZX, Liang Q, Liang YS, Tan XC, Guan LH (ed). Stored Product Proleclion. Proceedings of the $7 ' h$ international Working Conference on Stored-Product Protection; Beijing, 1419 Okt 1998. Chengdu: Sichuan Publishing House of Science \& Technology. lhlm 199-216.

Duniaji, A.S. 2009. Detection of aflatoxin B1Induced Cancer in several fried peanut products. " 3 rd International Workshop on Food Functional Clinical Research" 19 Sept 2009

Jay. JM. 2000. Modern Food Microbiology. Fourth Edition. Chapman and Maggon, KK; SK Gupta and TA. Venkitasubramanian. 1997. Biosynthesis of Aflatoxin. Bacteriological Review p 822-855. Department of Biochemistry, Vallabhbhai, Vatel hes Institute, University of Delhi India

Johnson, G. 1997. Reducing Aflatoksin in Peanut Using Agronomic Management and Biocontrol Strategies in Indonesia and Australia. Australian Centre for International Agricultural Research

Kasno, A. 2005, profiles and Peanut Production technique of Perkernbangan in Indonesia. Regular Seminar Acehnese remain vulnerable food plants: May 26, 2005. Bogor

King, A.D., A.D. Hocking and J.L. Pitt. 1979. Dichloran Rose engal Chlorampenicol Medium for Enumeration and Isolation of Mold from Food. Appl.Environ.Microbial. 37: 959-964.

Kozakiewics, Z. 1995. Mycotoxin Contamination in Grain: Occurrence and Significance of Storage Fungi Associated Mycotoxins in Rice and Cereal Grain. ACIAR. Australia. 18 19.

Kuswantoro, K. and S. Sudarmadji. 1988. The processes of Food Microbiology. PAU food and nutrition-University of Gajah Mada, Yogyakarta Duniaji, A.S., D.N. Suprapta and n. Arya. 2002. Isolation of Aspergillus flavus and Aspergillus parasiticus and Aflatoxin Detection on some types of foods sold in the city of Denpasar. Pathology Symposium. The Patobiologi Branch.

Loosmore, R.M., and L.M. Marksman, Poisoning of cattle by Brazilian groundnut meal, Vet. Rec. 73 (1961) 813 
Pitt J.I.; and Hocking AD, 1997, Funggi and Food Spoilage. London; Blackie Academic and Professional.

Pitt, J.I.; A. D. Hocking; O.S. Dharmaputra; K.R Kuswanto; E.S Rahayu; dan Sardjono. 1998. The Mycoflora of Food Commodities from Indonesia. Journal of Food Mycology I(1): 41-60

Saad, N. 2001. Aflatoxin Occurred and Health Risk. An Undergraduate Student Cornell University for the AS625 Class.
Animal Science at Cornell University. Pp 1-10.

Wilson, D.M., and G.A. Payne, Factors affecting Aspergillus flavus group infection and aflatoxin contamination of crops, in: D.L. Eaton, J.D. Groopman (Eds.), The Toxicology of Aflatoxins; Human Health, Veterinary, and Agricultural Significance, Academic Press, San Diego, CA, 1994, pp. 309325.

\section{How to cite this article:}

Duniaji, A.S., W. Putu Arisandhi, N.N. Puspawati and Ni Putu Novilia, C.D. 2018. Isolation of Aspergillus parasiticus and Detection of Aflatoxin B1 on Local Peanut (Arachis hypogaea L.) Varieties in Bali. Int.J.Curr.Microbiol.App.Sci. 7(08): 4636-4644.

doi: https://doi.org/10.20546/ijcmas.2018.708.489 